Podstawowe idee i koncepcje w geografii, t. 9

Nowe i stare perspektywy oraz ujęcia w geografii na przełomie XX i XXI wieku

http://dx.doi.org/10.18778/8088-505-9.02

\title{
Wiesław Maik
}

Wyższa Szkoła Gospodarki w Bydgoszczy

\section{DZIESIĘĆ LAT KOLOKWIUM TEORETYCZNO-METODOLOGICZNEGO - REFLEKSJE WSPÓŁORGANIZATORA}

Spotkania organizowane pod tym hasłem mają swoją dziesięcioletnią historię. Oceniając ich znaczenie i rezultaty naukowe warto odnieść się do kilku kwestii.

Po pierwsze, genezę kolokwium należy umieścić we właściwym kontekście historycznym, odnosząc ją do określonej fazy rozwoju geografii oraz swoistego klimatu intelektualnego w nauce przełomu stuleci, wyrażonym w przekonaniu, że kończy się dotychczasowy sposób uprawiania nauki, a nie wiadomo co przyniosą następne lata. Ta nowa sytuacja była w pełni odczuwalna także w środowisku geografów, chociaż jej rozpoznanie i opis napotykały jeszcze trudności.

Warto w skrócie przypomnieć ówczesne uwarunkowania. Przełom stuleci cechowały dynamiczne zmiany w nauce i w świecie. Zamiar uchwycenia tej zmienności oddaje pierwotna wersja hasła patronującego naszym spotkaniom, które w formie rozwiniętej brzmiało: „Podstawowe idee i koncepcje geograficzne w świetle przemian geografii i współczesnego świata". Ten dynamiczny rodowód kolokwium miał w praktyce organizowanych spotkań wielorakie odniesienia, obejmujące rozważania na temat zmian zachodzących w geografii w fazie postpozytywistycznej (postscjentystycznej), zmieniających się ujęć geograficznych w badaniach otaczającej rzeczywistości oraz funkcji nauki i geografii we współczesnym świecie. Należy pamiętać, że od kilkunastu lat trwa w geografii ożywiona debata nad teoretyczno-metodologicznymi podstawami tej dyscypliny, nasilają się spory dotyczące kondycji i tożsamości geografii w warunkach cechującego ją pluralizmu filozoficzno-metodologicznego. W tej sytuacji rodziła się potrzeba powrotu do źródeł i ożywienia debaty na temat podstawowych idei i koncepcji w geografii po to, aby móc lepiej i racjonalniej ocenić rozmaite 
nowe idee filozoficzno-metodologiczne przenikające do badań geograficznych.

Po drugie, warto przypomnieć przesłanki, które determinowały organizację i charakter tych spotkań. Punktem wyjścia w założeniach programowych organizatorów była ocena stanu geografii polskiej, a zwłaszcza jej niekorzystnych tendencji rozwojowych, takich jak nasilenie się zjawisk dezintegracyjnych, osłabienie nurtu rozważań ogólnogeograficznych oraz dyskusji nad metodami badań. $W$ tej sytuacji należało - zdaniem organizatorów - podjąć i rozwijać uogólniony dyskurs geograficzny poświęcony podstawom filozoficzno-metodologicznym geografii, jej roli w nauce i współczesnym świecie oraz związkom z innymi dyscyplinami naukowymi. Jednocześnie spotkania te miały - w naszym zamyśle - ułatwiać komunikację naukową pomiędzy przedstawicielami różnych dyscyplin geograficznych i pokoleń różniących się poglądem w sprawie tożsamości i jedności geografii oraz sposobu jej uprawiania, a także być miejscem prezentacji dokonań młodych badaczy. Te przesłanki określiły charakter spotkań. Wskazywała na to zresztą ich nazwa - kolokwium jako forum rozmowy i refleksji nad specyficznym oglądem świata przez geografię i geografów. Zakładaliśmy więc a'priori otwartą formułę spotkań, a ich ważną częścią miały być dyskusje i polemiki. To wszystko kształtowało specyficzną atmosferę spotkań, umożliwiającą swobodną wymianę myśli.

Tematyka dotychczasowych dziewięciu spotkań była różnorodna, szeroko zarysowana, z ukierunkowaniem na debatę dotyczącą podstawowych idei i koncepcji w geografii. Pewną specyfiką spotkań była ich zmienność pod względem przestrzennym i formalnym. Odbyły się one w trzech miejscach: Toruniu, Łodzi i Bydgoszczy pod patronatem kolejno trzech uczelni: Uniwersytetu Mikołaja Kopernika, Uniwersytetu Łódzkiego i Wyższej Szkoły Gospodarki.

W tematyce kolokwiów brak jest, na pierwszy rzut oka, jakiegoś uporządkowania, pewnego spójnego w układzie logicznym wynikania problematyki (tabela, s. 18.). Nie chcemy post factum idealizować naszych wyborów - wynikały one raczej z osobistych zainteresowań i poglądów inicjatorów tych spotkań. Każdy z nas niejednokrotnie nieco inaczej postrzegał i identyfikował tematy ważne $w$ dyskusji. Pomimo pewnych różnic istniała jednak między nami pewna zgoda w kilku istotnych sprawach. Wynikała ona z konstatacji akceptowanej przez nas koncepcji geografii jako nauki oraz diagnozy jej aktualnego stanu. Były to pewnego rodzaju zworniki organizujące nasze działania w całość, budujące wspólnotę naszych poglądów. Wśród nich należy wymienić trzy założenia (tezy) wyrażające - explicite lub implicite - nasze oczekiwania dotyczące dalszego rozwoju geografii.

Po pierwsze zakładaliśmy, że współczesna geografia powinna być „rozpięta" pomiędzy dążeniem do ochrony jej jedności i tożsamości a rozwojem poszczególnych subdyscyplin geograficznych wnoszących szybki przyrost wiedzy specjalistycznej oraz poszerzanie pola badawczego. Można 
stwierdzić, że problematyka tożsamości i jedności geografii była obecna na prawie wszystkich spotkaniach, zwłaszcza zaś na kolokwiach $\mathrm{nr} 1 \mathrm{pt}$. Geografia jako nauka o przestrzeni, środowisku i krajobrazie (Toruń, 2004), nr 2 nt. Człowiek w badaniach geograficznych (Łódź, 2005), nr 6 pt. Geografia regionalna - scalenie i synteza wiedzy geograficznej (Łódź, 2009), nr 4 pt. Terytorium, region, miejsce - czas i przestrzeń w geografii (Łódź, 2007).

Po drugie, zakładaliśmy, że rozwój geografii powinien być „rozpięty” pomiędzy potrzebą zachowania tradycji myśli geograficznej a koniecznością jej modernizacji i rekonstrukcji problemowej i teoretyczno-metodologicznej. Wynikało to z przekonania, że rozwój geografii powinien mieć charakter ewolucyjny i opierać się na dwóch zasadach: historycznej ciągłości i racjonalności zmian wewnątrz dyscypliny. Inaczej mówiąc proces wyłaniania się intelektualnych innowacji musi być „osadzony” w tradycji geograficznej i podlegać z tego punktu widzenia krytycznej selekcji. Świadomość ta wyznaczała tematykę kilku spotkań - przede wszystkim kolokwium nr 1 nt. podstawowych idei i koncepcji w geografii (Toruń, 2004), kolokwium $\mathrm{nr} 2 \mathrm{nt}$. problematyki człowieka w badaniach geograficznych (Łódź, 2005), kolokwium nr 3 nt. roli geografii w badaniu przemian współczesnego świata (Bydgoszcz, 2006), kolokwium nr 5 nt. ujęć i problemów badawczych we współczesnej geografii (Bydgoszcz, 2008), kolokwium nr 9 nt. dorobku polskiej geografii po konferencji w Rydzynie (Łódź, 2012) oraz planowanego spotkania w Spale (2014) nt. nowych perspektyw i ujęć w geografii na przełomie XX i XXI w.

Po trzecie, byliśmy przekonani o potrzebie rozwijania świadomości filozoficzno-metodologicznej w środowisku geografów akademickich. Postuluje ona niezbędność nieustannej debaty na temat historii intelektualnej geografii, w tym geografii polskiej, a także podstawowych koncepcji i idei geograficznych. Można z pewnym uproszczeniem stwierdzić, że istniejące prace poświęcone historii geografii w Polsce stanowią w znacznej mierze prezentację wydarzeń, problematyki, rozwoju poszczególnych dyscyplin i ośrodków geograficznych. Brak w nich rekonstrukcji przemian świadomości metodologicznej, określenia momentów zwrotnych w rozwoju dyscypliny, analizy przejścia od jednego ładu paradygmatycznego do drugiego. Stwierdzić można, że takie próby były obecne w naszych spotkaniach poczynając od kolokwium nr 1 nt. podstawowych koncepcji i idei w geografii (Toruń, 2004) do planowanego kolokwium poświęconego nowym perspektywom i ujęciom we współczesnej geografii (Spała, 2014).

Podsumowując, warto odpowiedzieć na dwa pytania: czy wszystkie zamysły organizatorów spotkań zostały zrealizowane? oraz jakie są ich efekty? Generalnie biorąc, nasza ocena jest pozytywna, chociaż zdajemy sobie sprawę, że może być ona subiektywna. Istotnym walorem tych spotkań naukowych - zgodnie z pierwotnym zamysłem organizatorów - była rewitalizacja dyskusji na tematy ogólnogeograficzne w ujęciu teoretyczno-metodologicznym, osadzona w kontekście powrotu do źródeł geografii 
jako nauki. Niewątpliwym efektem naukowym - oprócz organizacji konferencji naukowych i żywej dyskusji na tych spotkaniach - jest publikacja dziewięciu tomów zawierających materiały $\mathrm{z}$ obrad $\mathrm{w}$ postaci tekstów wygłoszonych referatów oraz toczącej się dyskusji. Naszym zdaniem prace te mogą mieć istotne znaczenie dla młodego pokolenia geografów, wkraczających w świat wiedzy geograficznej: studentów, doktorantów i młodszych pracowników naukowych. Warto zaznaczyć także, że wspomniane spotkania cieszyły się pewnym zainteresowaniem, gromadziły przedstawicieli różnych pokoleń geografów, z prawie wszystkich ośrodków geograficznych. 